\title{
SIGNALLING EFFECT OF AUDITOR REPUTATION AND LOCK-UP PERIOD ON OVER-SUBSCRIPTION RATIO: EVIDENCE FROM MALAYSIAN FIXED-PRICE IPOS
}

\author{
Ali Albada* \\ Xiamen University Malaysia \\ Othman Yong \\ Universiti Kebangsaan Malaysia \\ Soo-Wah Low \\ Universiti Kebangsaan Malaysia
}

\begin{abstract}
This study investigates the signalling effect of auditor reputation and lock-up period on the subscription demand of investors in the Malaysian IPO market that uses the fixed-price method in pricing IPOs. The study sample covers 420 IPOs listed on Bursa Malaysia from January 2000 to December 2015. The present study employs Ordinary Least Square (OLS) and Quantile Regression (QR) methods in investigating the signalling effect on over-subscription ratio (OSR). The results indicate that auditor reputation has a negative effect and the lock-up period has a positive effect on OSR. This shows that investors' demand in Malaysia is driven by capital gain and not by the quality of the listing firm. This is also supported by the control variables, where IPOs with low initial return, high offer price, high institutional involvement, and reputable underwriter have lower OSR because they have lower initial returns.
\end{abstract}

Keywords: Auditor reputation; Fixed-price method; Lock-up period; Malaysian IPO market; Oversubscription ratio; Quantile regression.

Received: 21 November 2018

Accepted: 26 August 2019

\section{INTRODUCTION}

In Malaysia, the fixed-price method is one of the most popular methods used in setting the offer price of listing firms (Albada, Low, \& Yong, 2019a; Low \& Yong, 2013; Yong, 2015). In fixedprice method, the offer price of the new issue is set prior to the listing date by the promoter and the underwriter (Badru \& Ahmad-Zaluki, 2018; Yong \& Albada, 2018; Yong, 2015). This means that in the fixed-price method, the listing firm is unable to gauge investors' demand for its issues, suggesting that the listing firm is facing an unknown market demand regarding their issues (Low \& Yong, 2011). This lack of pre-market demand regarding the listing firm's issues puts the issuing firm at a disadvantage (Low \& Yong, 2011). According to Vong (2006), one of the essential roles

\footnotetext{
* Corresponding Author: Ali Albada, School of Economics and Management (SEM), Xiamen University Malaysia, 43900, Sepang, Malaysia. Email: ali.albada@xmu.edu.my.
} 
in IPO success is investors' demand because it provides the issuing firm with the needed information regarding market's reaction for its issues. This is important, because gauging investors' demand allows the listing firm to estimate if it has a better opportunity in selling more shares in the future (Vong, 2006), which can also provide an estimate of future liquidity opportunities (Alanazi, Liu, \& Al-Zaoubi, 2016; Loughran \& Ritter, 1995). According to Ritter (1998), the enhanced liquidity enables the company to raise capital on more favourable terms in the future rather than having to compensate investors for the lack of liquidity. Finally, investor demand is a key determinant factor of IPO success, especially in Malaysia that employs the fixed-price method in pricing IPOs (Low \& Yong, 2011).

Over-subscription ratio (OSR) provides the listing firm with a beam of hope in measuring investors' demand (Albada, Yong, \& Low, 2019c; Low \& Yong, 2011). According to Albada et al. (2019c), OSR is able to measure investors' demand for the listing firm's issues because OSR represents the number of times an IPO is oversubscribed. Furthermore, according to Chowdhry and Sherman's (1996) model, most of the markets that use the fixed-price method, especially Asian IPO markets, are faced with high OSRs and initial returns than countries that use the book-building method. This because OSR build on the assumption that the demand for the issues is higher than the issues supplied by the listing firm, which means the moment the issues are available for trading all of the investors who have subscribed for the issues will bid them (Abdul-Rahim \& Yong, 2010). This sudden high demand for the listing firm's issues will put pressure on the after-market price and thus resulting in higher initial return due to the higher price drift. In this paper, we report an average OSR of 32.69 times for a sample of 420 Malaysian IPOs during the period from 2000 to 2015 (see Table 1). This figure is lower than the average of 44 times reported by Dawson (1987) for 21 IPOs from 1978 to 1984, an average of 43.71 times reported by Yong and Isa (2003) for 462 IPOs from 1990 to 1998, and average of 41.14 times reported by Taufil-Mohd (2007) for 539 IPOs from 1996 to 2002 and higher than the average of 23.21 times reported by Tajuddin et al. (2018) for 252 IPOs from 2005 to 2015. Moreover, the OSR reported by this study is similar to the average 33.59 times reported by Low and Yong (2011) for 252 IPOs from 2005 to 2007, and an average of 32.44 times reported by Abdul-Rahim and Yong (2010) for 386 IPOs from 1999 to 2007. Furthermore, from Table 1 the minimum OSR reported for the study sample is -0.89 and the maximum OSR is 377.96. The huge difference in the over-subscription ratio supports the motivation of this study to examine factors that could potentially influence investor demand in the Malaysian IPO market.

The Malaysian market is an emerging market and for it to reach new heights, the listing requirements in the Malaysian capital market encourage small and young companies to raise capital through IPOs (Badru \& Ahmad-Zaluki, 2018). Furthermore, the fixed-price method is the preferable choice by those listing firms that are characterised by higher price uncertainty and greater concern for risk (Benveniste \& Busaba, 1997). Moreover, small issues have the advantage in the fixed-price than in the book-building because they are exposed to lower risk and fixed cost (Benveniste \& Busaba, 1997). Finally, the capital market in Malaysia as described by Yong (2013) is "not-so-liquid" and has high uncertainty, which encourages issuers to lean toward the fixed-price method (Loughran, Ritter, \& Rydqvist, 1994). In addition, both the listing frim and the underwriter have greater freedom in deciding the offer price (Tajuddin, Mohd rashid, Abdullah, \& AbdulRahim, 2015), unlike the book-building where the offer price is determined by compiling and comparing bids among groups of investors (Tajuddin et al., 2015). However, the Securities Commission (SC) of Malaysia has the final say in what the final offer price should be, for the 
purpose of ensuring fair value in the new issues (Abdul-Rahim \& Yong, 2010). Finally, according to Tajuddin et al. (2015), uninformed investors in the fixed-price method are faced with lower adverse selection cost than in the book-building because of the higher uncertainty involved in determining the price in the book-building method. The previous mentioned reasons helped to explain the popularity of the fixed-price method for pricing IPOs in Malaysia (Albada et al., 2019a; Low \& Yong, 2013; Yong \& Albada, 2018; Yong, 2015).

The signalling theory is the binding force that glue this paper together. In short, we argue that the ex-ante information available to investors is able to signal the quality of the listing firm to the market and help the listing firm in gaining the attention of prospective investors, which lead to high OSR (Albada et al. 2019c; Tajuddin, Abdullah, \& Taufil-Mohd, 2018). The present study is interested in some ex-ante information that is able to signal the quality of the listing firm and could influence the subscription demand of the listing firm's issues. Specifically, the current study is interested in two signalling variables, namely the auditor reputation and lock-up period. This study is interested in the auditor reputation as a response to the comment made by Yong (2007), who suggested that the effect of auditor reputation on IPOs lacks in the Asian region, especially in Malaysia. Furthermore, the study is interested in investigating if the lock-up period has lost its signalling properties due to enforced regulatory in the Malaysian market that restricts the issuing firm to a mandatory fixed lock-up period of 1 year or 6 months (Albada, Low, Yong, Nassir, Kamarudin, \& Anwar, 2019b). Moreover, according to Tajuddin et al. (2018), the Malaysian literature is lacking on factors that may influence OSR in the Malaysian market, where OSR is considered unique for the fixed-price method as it is non-existence in the book-building method. Another interest of the present study, is to investigate if IPO subscription in the Malaysian IPO market is driven by the initial capital gain or by the quality of the issuing firm. Ritter and Welch (2002) argued that some of the ex-ante information available to the public is able to reduce investors' heterogeneity of opinion by signalling the quality of the issuing firm to the market. According to Beatty and Ritter (1986), high-quality firms that seek to avoid unnecessary underpricing, would present lower risk profile characteristics to potential IPO investors through signalling. Therefore, the signal used by the listing firm is able to reduce (increase) the underpricing cost it has to bear during the listing process, which minimises (maximises) the capital gain available for prospective investors. The literature has shown the ability of the study variables in signalling the quality of the listing firm to prospective investors and in influencing the initial return of the listing firm. Sundarasen, Khan, \& Rajangam (2017), Khurana, Ni, \& Shi (2017) and Albada et al. (2019a) documented that reputable auditors are able to signal the quality of the listing firm by reducing the level of information asymmetry surrounding the listing firm's issues because quality auditors are costly and can only be afforded by high-quality issuing firms and they reduce the under-pricing cost that the listing firm has to bear during listing. Furthermore, Courteau (1995), Mohd Rashid, Abdul-Rahim, \& Yong (2014) and Albada, Yong, Hassan, \& Abdul-Rahim (2018) reported that the lock-up period can be used to signal the quality of the listing firm through undertaking longer lock-up periods, because longer periods subject the insiders to hold undiversified portfolios that consist mainly of their firm's issue and increase initial returns. On the other hand, Huang, Chiang, Lin, \& Lin (2017) and Moshirian, Ng, \& Wu (2010) documented that an emerging market such as Malaysia is characterised by high IPO abnormal returns (capital gain) due to the use of the fixed-price method. Moreover, this abnormal return can motivate investors in the short-run which cause an overreaction that leads to excessive optimism among investors (Huang et al., 2017). 
Low and Yong's (2011) study was one of the first studies to contribute to the Malaysian literature through investigating the effect of some of the pre-listing actions taken by the listing firm in influencing the IPO subscription for its issues. These actions are related to the issuing firm's decision in determining the offer price, issue size, timing of the IPO (hot issue market), and the length of the offer period. Low and Yong (2011) concluded that the market timing and the offer price are big influencer in deciding the subscription demand for listing firm's issues, especially in times of high initial returns and low volume of IPO activities. In a most recent study Tajuddin et al. (2018) investigated the impact of Sharia-compliant status IPOs on OSR. They concluded that Sharia status could draw the attention of the investors through increasing OSR. The present study, extends both Low and Yong's (2011) and Tajuddin et al. (2018) studies by investigating other prelisting actions that may influence the subscription demand for listing firm's issues. Specifically, in this study we investigate the effect of auditor reputation and lock-up period in determining the OSR for the listing firm's issues in the Malaysian IPO market. Moreover, the present study also contributes to the Malaysian literature through extending the work of Mohd Rashid et al. (2014) by investigating the effect of lock-up period on OSR. In their study, Mohd Rashid et al. (2014) examined the effect of lock-up period and lock-up ratio on IPO initial return. They documented that the effect of the lock-up period is more pronounced than the effect of the lock-up ratio, and the lock-up periods were more appropriate for signalling the quality of the firm.

Finally, the current study differentiate itself from the previous literature by implementing the quantile regression (QR) method in addition to the ordinary least square (OLS) method. We have selected the QR method due to its ability to overcome the shortcoming of the OLS method in terms of the non-normality of the data and heteroscedasticity, and it is robust to outliers due to the ability of the QR to explain the low and high of the dependent variable (Badru \& Ahmad-Zaluki, 2018). This is can be done through the quantile representation (e.g. 25th, 50th and 75th) of the dependent variable distribution. Furthermore, the QR method allows us to investigate the "influencing effect" of the independent variables at different points of the distribution of the dependent variable (Badru \& Ahmad-Zaluki, 2018). The results for the normality of the residuals through the Shapiro-Wilk $\mathrm{W}$ test show a p-value $<0.01$, therefore rejecting the null hypothesis of the normal distribution for the dependent variable, which is the OSR. Moreover, Table 1 and Figure 1 shows the variations in the mean, maximum and minimum values of OSR.

The present study contributes to the literature by showing that investors in the Malaysian IPO market are driven by capital gain and not by the quality of the signalling firm, where the results show that IPOs with reputable auditor, short lock-up period, low initial return, high offer price, high institutional involvement, and reputable underwriter face lower demand than other IPOs. This is because the previous factors help in reducing the initial return of the listing firm, which cause such IPOs to face lower OSR.

Table 1: Descriptive Analysis

\begin{tabular}{cccccc}
\hline \hline Variable & Observations & Mean & Std. Dev. & Min & Max \\
\hline OSR & 420 & $\mathbf{3 2 . 7 0}$ & 48.97 & $\mathbf{- 0 . 8 9}$ & $\mathbf{3 7 7 . 9 6}$ \\
Initial return & 420 & 31.21 & 44.42 & $\mathbf{- 6 6 . 9 8}$ & $\mathbf{2 8 8 . 8 9}$ \\
Offer price & 420 & $\mathbf{0 . 9 6}$ & $\mathbf{0 . 6 5}$ & $\mathbf{0 . 1 2}$ & 4.8 \\
\hline \hline
\end{tabular}


Figure 1: Quantile Plot for OSR

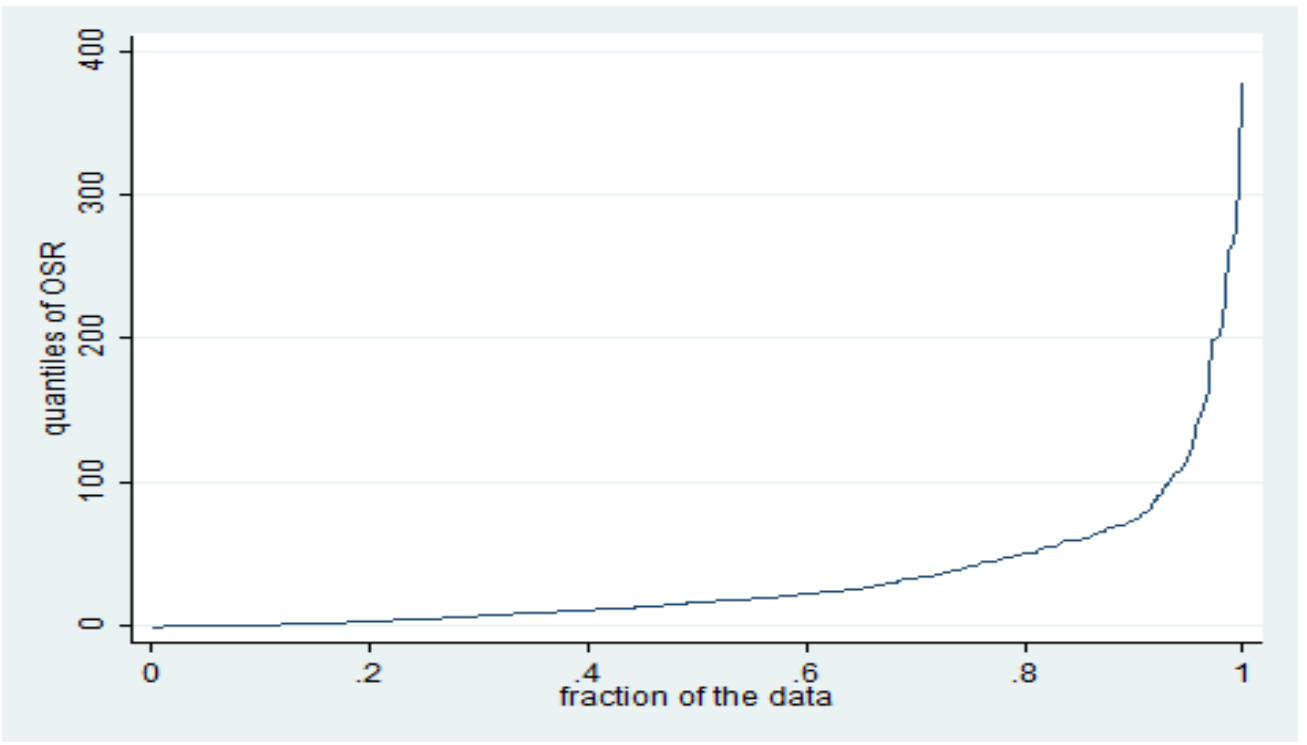

The remaining of this paper is organised as follows. Section 2 discusses the literature of the study, while Section 3 presents the data and methodology employed in this study. The results are presented in Section 4. Finally, Section 5 concludes the paper.

\section{LITERATURE REVIEW}

This interest is stemmed from several theories, one of which is the theoretical explanations of signalling theory for oversubscription (Allen \& Faulhaber, 1989; Grinblatt \& Hwang, 1989; Welch 1989). The signalling hypothesis is built on the essence that high-quality firms use under-pricing as a strategy to reflect their quality to prospective investors and to discourage low-quality firms from competing against them in the IPO market. However, Bhabra and Pettway (2003) argued that under-pricing is not the only signal the listing firm can use to signify its quality. Building on Spence (1973) argument, investors can make use of the available information in the prospectus to look for signals that can help them in reducing their uncertainty regarding the listing firm's quality. In their study, Bhabra and Pettway (2003) reported that investors' decision relating to the subscription to the IPOs must rely mainly on signals provided in the prospectus such as firm size, relative offer size, VC backing, and underwriter prestige. In this study, we argue that auditor reputation and lockup period can be used as signals to indicate the listing firm's quality, which in turn help in increasing the subscription for the listing firm's issues.

Another theoretical explanation for oversubscription is provided by Rock's (1986) winner curse model. Rock (1986) argued that under-priced IPOs receive subscription from both informed and uninformed investors, while over-priced issues receive subscription from uninformed investors. This means that profitable IPOs have higher over-subscription ratio than over-priced issues because it receives demand from both informed and uninformed investors. Furthermore, Welch's 
(1992) bandwagon effect provides another theoretical explanation for the oversubscription demand. Welch (1992) argued that investors in the market do not only rely on ex-ante information to make investment decision, they also take the actions of informed investors into consideration. In other words, investors make their decisions by observing the decisions or choices of others. According to Ljungqvist (2008), informed investors may not engage in an investment if they found that other investors are not willing to invest in, even though they have favourable information. In Malaysia, Yong (2011) found that investors over-react to IPOs with large group of informed investors, which are presented by institutional investors.

According to Spence (2002), signalling theory is concerned with reducing information asymmetry between two parties. Specifically, the listing firm is able to utilise some of the ex-ante information to signify its quality to the market, which help the listing firm in reducing the level of information asymmetry surrounding its issues (Ritter \& Welch, 2002), reducing under-pricing (Beatty \& Ritter, 1986), and establishing its quality over other low-quality IPO firms (Allen \& Faulhaber, 1989). According to Michaely and Shaw (1994), issuing firms use signalling as a tool to reduce agency costs by conveying the message that are too costly for low-quality firms to imitate. The literature has established the ability of auditor reputation to signal the quality of the listing firm (Michaely \& Shaw, 1995), by being a costly signal which low-quality firms cannot imitate easily (Sundarasen et al., 2017), to reduce the level of information asymmetry surrounding the listing firm's issues (Khurana et al., 2017), and to reduce the under-pricing cost that the listing frim has to bear (Michaely \& Shaw, 1995; Khurana et al., 2017).

Rumokoy, Neupane, Chung, \& Vithanage (2017) utilized the social network analysis to investigate the effect of underwriter network centrality within the investment banking industry on IPOs outcomes in the China's primary market between 2006 and 2012. They documented that the network centrality improved the underwriter capability of drawing a high number of institutional investors through effectively tapping into peers' institutional client base. They concluded that hiring a more central underwriter could be used as a signal to indicate the quality of the issuing firm. Khurana et al. (2017) investigated the effect of auditors' reputation on IPO under-pricing using a comprehensive sample of 14,029 IPOs from 37 countries over a period of 1995 to 2014. Their study sample covered the following Asian countries: Australia, China, Hong Kong, India, Indonesia, Japan, Malaysia, New Zealand, Philippines, Singapore, Taiwan, and Thailand. They documented, after controlling for country, industry, and year-fixed effects, that issuing firms with Big 4 auditors were associated negatively with under-pricing, especially in IPO markets where investor protection laws were weak. Furthermore, they argued that issuing firms in countries plagued with weak legal regimes could use auditor reputation as a signalling tool to signify their quality and reducing the cost of issuing new equity.

The literature has shown that the lock-up period is considered a costly signal because insiders hold undiversified portfolios that consist mainly of their firm's issue, and the longer the period is, the higher the price will become (Courteau, 1995). Furthermore, according to Mohd Rashid et al. (2014), lock-up period can reduce the level of information asymmetry around the listing firm's issues through signalling the quality of the listing frim. However, the lock-up period in the Malaysian IPO market is different from other markets (for example the US and UK) because the listing firm is forced to implement a mandatory lock-up period starting from May 3, 1999. According to the Securities Commission Act of 1999, promoters (original shareholders) that seeking listing on the Main Board and Second Board are not allowed to sell off more than $45 \%$ of 
the offeredissues for a period of one year from the date of listing. Furthermore, the same rule applies on the promoters seeking listing on the MESDAQ. However, the promoters are required to hold at least $51 \%$ off the offered issues. The lock-up agreement has gone through phases of changes but the most forceful lock-up agreement was put forth during the 2009 for the purpose of protecting investors' interests (Mohd Rashid et al., 2014). This means that all firms listed from 1999 to 2009 have a mandatory 1 year lock-up period and firms listed after 2009 have a mandatory 6 months lock-up period. Such enforcement of the lock-up agreement differentiates the Malaysian IPO market from the rest of the world, especially from the US and UK IPO markets. In developed countries, the implementation of the lock-up agreement is built on an optional basis that depends on the outcomes of the negotiations between the insiders of the IPO companies and the investment bank (Brav \& Gompers, 2003; Mohan \& Chen, 2002). Building on the unique rules that govern the lock-up period in the Malaysian market, the authors argue that prospective investors in the IPO market do not rely on the ex-ante information regarding the lock-up period in building their investment decision.

In their study, Boonchuaymetta and Chuanrommanee (2013) were interested in investigating the relationship between underwriter reputation, ownership concentration, book-building, IPO allocation, the length of the lock-up period, and investor interest and IPO under-pricing in the Thailand IPO market. They covered 153 IPOs listed between 2001 and 2011. They found that IPO allocation was the strongest factor in influencing under-pricing in a negative relationship. They also found that the length of the lock-up period, issue size, industry, and hot issue market had significant positive relationships with under-pricing. Finally, they argued that provision thatcould restrain insider dealing such as a longer lock-up period could yield a higher initial return and changing the ownership concentration by a small percentage did not affect under-pricing. In Australia, both mandatory lock-ups (ML) and non-mandatory lock-ups (NML) firms co-exist. This is because, in the Australian regulatory setting, ML is applied to insider shares of IPO firms that do not satisfy profit or asset tests. Taking advantage of this unique IPO policy, Haman, Chalmers, \& Fang (2017) investigated the effect of different lock-up types on long-run returns (buy-hold abnormal return at the fifth year post listing). Their study sample consisted of 571 IPO firms listed on the Australian Securities Exchange (ASX) and covering the period from 2003 to 2007. Their sample contained 460 firms with ML only and 111NML. They indicated that the average marketadjusted under-pricing of ML firms was significantly lower than for NML firms, at the one percent level. Furthermore, they reported that an increase in market-adjusted returns by one percent decreases long-run returns by 0.47 percent. Moreover, they showed that insider equity ownership subject to lock-ups, the weighted average number of days of the lock-ups, the natural logarithm of the number of days from the registration of an IPO prospectus to the IPO listing date, and reputable underwriter had a positive relationship with long-run returns. On the same subject, their study concluded that long-run returns for ML firms were significantly lower (higher) than for NML firms, and good corporate governance was positively associated with long-run returns for both lock-up type firms. Finally, they found that the listing survival rate of ML firms was higher than for NML.

In fixed-price method, the offer price is set between the issuing firm and the underwriter. Moreover, prospective investors are not able to participate in setting the offer price, which means that the offer price does not reflect the investors' sentiment and expectations. Therefore, the offer price must be discounted in order to neutralize the potential adverse effect of lack of investor interest (Benveniste \& Busaba, 1997). This means if the offer price is higher than prospectors' 
investor expectation the OSR will be lower because as there is no gain from participating. In this regard, Moshirian et al. (2010) concluded that investors prefer to invest in the IPOs of such developing markets, such as Malaysia, because they can earn abnormal returns by subscribing to the newly issued shares during the first day of listing and sell them at the end of the listing day. Moreover, according to Huang et al. (2017), fixed-price IPOs experience significant short-run overreactions due to greater initial returns which causes excessive optimism among investors. Building on the previous arguments, the present study controls for the offer price, investors' sentiment, private placement (institutional investors) and reputable underwriter.

\section{DATA AND METHODOLOGY}

The study sample includes all IPOs listed on Bursa Malaysia from January 2000 to December 2015. Furthermore, the study sample only consists of IPOs that are priced using the fixed-price method. Therefore, the study excludes those IPOs that listed through the book-building method. During the period of this study, there were less than ten IPOs that used the book-building pricing method. Further information is available at the Bursa Malaysia website (http://www.bursamalaysia.com/market/listed-companies/initial-public-offerings/ipo-summary/). Moreover, the final study sample does not include the following issues: restricted offer-for-sale, restricted public issue, restricted offer-for-sale to eligible employees, restricted offer-for-sale to Bumiputra (it refers to Malays and indigenous people) investors, special and restricted issues to Bumiputra investors, tender offers, and special issues) because these issues are not available for subscription by the general public Abdul-Rahim and Yong (2010), Yong (2007), and Mohd Rashid et al. (2014). In addition, the final study sample excludes Real Estate Investment Trust (REIT) IPOs because REIT uses different presentation format of their financial statements (Mohd Rashid et al., 2014). Finally, all the data were manually extracted from various sources, namely: (1) Bursa Malaysia website (http://www.bursamalaysia.com/market/listed-companies/initial-publicofferings); (2) Yahoo Finance Singapore (https://sg.finance.yahoo.com); and (3) the Star Online website (https://www.thestar.com.my/business/marketwatch/ipo/). The data on the oversubscription ratio is not readily available, and so we have to rely on various newspapers' reports such as Star Online (http://www.thestar.com/business/business-news), and one-million-dollar blog (http://1-million-dollar-blog.com/category/stock-market/initial-public-offering).

Table 2 summarises both the IPOs distribution of the study population as well as the final sample of 420 IPOs. The distribution of the population and the final sample are established based on the year of listing.

Table 2: Distribution of the Study Sample Based on the Year of Listing (From 2000 to 2015)

\begin{tabular}{|c|c|c|c|c|c|c|c|c|c|c|c|c|c|c|c|c|c|}
\hline $\begin{array}{l}\text { Listing } \\
\text { Year }\end{array}$ & ఫ్రి & હ్ & క్రి & ๕్ & ఫ్ & 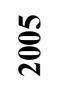 & ఫ్రి & હ్సે & 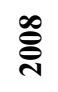 & હे̀ે & 을 & $\overline{\bar{乛}}$ & 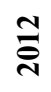 & $\stackrel{m}{\bar{N}}$ & $\stackrel{\Xi}{\vec{N}}$ & 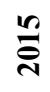 & Total \\
\hline Population & 38 & 20 & 51 & 58 & 79 & 79 & 40 & 30 & 23 & 14 & 29 & 21 & 17 & 17 & 15 & 13 & 544 \\
\hline $\begin{array}{c}\text { Final } \\
\text { sample }\end{array}$ & 30 & 15 & 41 & 53 & 66 & 67 & 30 & 18 & 12 & 12 & 21 & 20 & 9 & 9 & 10 & 7 & 420 \\
\hline
\end{tabular}


Equation (2) presents the multiple regression that is employed using the OLS and QR regression models to examine the influence of auditor reputation and lock-up period on OSR.

$$
\mathrm{OSR}=\alpha+\beta_{1} \mathrm{UA}_{i}+\beta_{2} \mathrm{LP}_{i}+\beta_{3} I_{i}+\beta_{4} \mathrm{PP}_{i}+\beta_{5} \mathrm{OFFP}_{i}+\beta_{6} \mathrm{UR}_{i}+\varepsilon_{i}
$$

$O S R$, is investors' demand for an IPO, which is proxied by the over-subscription ratio as shown in Equation (1). $U A$ refers to a dummy variable that represents auditor reputation, which takes a value of 1 for the top two reputable auditors and 0 otherwise. Throughout the study sample we have managed to record more than 68 auditing companies. However, out of those we managed to find only two auditing firms that have audited 50 IPOs and more, which are Ernst \& Young and KPMG. Both have prepared the auditing report for 34 percent of the IPOs in the study sample. LP is the lock-up period which is represented by a dummy variable that takes the value of 1 for a lock-up period of 360 days and above and 0 otherwise. The same method was implemented by Mohd Rashid et al. (2014). IS represents investors' sentiment toward an IPO, which takes the value of 1 for firms with initial return higher than the average IPO initial return for the whole year and 0 otherwise. Tajuddin et al. (2018) implemented the same method taking the average initial return of IPOs in a particular month. However, the present study took the whole year approach because there were only a few issuing firms available during the year and those firms were listed in different months. For example, in the year 2015, only seven firms were listed. Moreover, the initial returns are calculated by subtracting the opening price of an IPO with the offer price of an IPO then divide it by the offer price. This method is called the offer-to-open method, which was implemented by Yong (2011) and Yong and Albada (2018).

$$
\text { OSR }=\frac{\text { Total number of IPOs Subscribed }}{\text { Total Offer Units }}
$$

PP represents private placement (institutional investor involvement), which takes a value of 1 to represent firms with private placement and 0 otherwise. OFFP is the offer price of an IPO. UR is a dummy variable for underwriter reputation that takes a value of 1 for Big 3 underwriter and 0 otherwise. The current study measures underwriter and auditor reputations using the number of issues that an investment bank or auditing firm has underwritten or audited as lead manager or lead auditor. In other words, the Big 3 underwriters or Big 2 auditors are those with the highest proportion of underwritten or audited issues in the IPO market. Such reputation criteria have been employed by Jelic, Saadouni, \& Briston (2001) and Dimovski, Philavanh, \& Brooks (2011) to measure underwriter reputation, and by Megginson and Weiss (1991) to measure auditor reputation.

\section{RESULTS}

Table 3 presents the Pairwise correlation between OSR and the study variables. Table 3 shows that reputable auditor has a significant negative relationship with OSR at the 5 percent level and the lock-up period has a significant positive relationship with OSR at the 5 percent level. These initial results contradict our initial thoughts that reputable auditors are able to increase OSR and lock-up period does not have a significant relationship with OSR because of the mandatory regulations implemented in the Malaysian IPO market. Furthermore, the results in Table 3 show that out of the four control variables only three has a significant relationship with OSR at the 5 percent level, 
where both the offer price and reputable underwriters have negative relationship and investors' sentiment has a positive relationship with OSR.

Table 3: Pairwise Correlations Between OSR and the Study Variables $(\mathrm{N}=420)$

\begin{tabular}{cccccccc}
\hline \hline$\#$ & Variables & OSR & $\mathbf{2}$ & $\mathbf{3}$ & $\mathbf{4}$ & $\mathbf{5}$ & $\mathbf{6}$ \\
\hline 2 & Reputable Auditor & $-0.1058^{* *}$ & 1 & & & & \\
3 & Lock-up period & $0.1000^{* *}$ & -0.0622 & 1 & & & \\
4 & Investors' sentiment & $0.3093^{* *}$ & 0.0087 & -0.0015 & 1 & & \\
5 & Private Placement & -0.0851 & -0.0707 & -0.06 & 0.0287 & 1 & \\
6 & Offer price & $-0.2084^{* *}$ & 0.0447 & -0.0036 & $-0.1152^{* *}$ & $-0.3521^{* *}$ & 1 \\
7 & Reputable underwriter & $-0.1404^{* *}$ & $0.1396^{* *}$ & -0.0547 & -0.0225 & 0.0064 & $0.1293^{* *}$ \\
\hline \hline
\end{tabular}

Note: ** denotes statistical significance at the 5 percent level.

Table 4 shows the results of the OLS, robust OLS and QR regression between OSR and the study variables. The OLS results show that reputable auditors have a significant negative effect on OSR at the 5 percent level. Furthermore, the QR results show that reputable auditors have a significant negative relationship with OSR at the lower quantile (25th). Both results indicate that IPOs with reputable auditors have lower OSR than IPOs with less reputable auditors, which indicates that investors try to avoid IPOs with reputable auditor because these IPOs tend to have less initial return. The literature has shown that an effective signal is able to reduce the under-pricing cost that the listing firm has to bear during the listing process. For example, Khurana et al. (2017) documented that Big 4 auditors were associated with lower under-pricing. Their study covered 14,029 IPOs from 37 countries over a period of 1995 to 2014. Furthermore, Badru and AhmadZaluki (2018) documented that reputable auditor in Malaysia is able to reduce the ex-ante uncertainty regarding IPOs, which leads to lower initial return. Building on the previous argument, we infer that investors in the Malaysian market use the ex-ante information regarding the auditing firm in evaluating the initial returns and not the quality of the listing firm because IPOs with reputable auditor has lower initial return than IPOs with less reputable auditor. This is in alignment with Moshirian et al. (2010) argument, where they argued that investors in a developing market such as Malaysia are driven by quick capital gain from selling IPOs during the first-day of listing.

Table 4: OLS and Quantile Regression Between OSR and the Study Variables

\begin{tabular}{lccccc}
\hline \hline $\begin{array}{l}\text { Variable } \\
\text { Dependent: OSR }\end{array}$ & OLS & Robust OLS & \multicolumn{3}{c}{ QR } \\
\hline Reputable auditors & $-9.663^{* *}$ & $-9.663^{* *}$ & $-3.401^{* *}$ & -4.934 & -3.359 \\
& $(-2.07)$ & $(-2.46)$ & $(-2.10)$ & $(-1.28)$ & $(-0.50)$ \\
Lock-up period & $8.035^{*}$ & $8.035^{*}$ & -0.171 & 4.572 & $16.36^{* *}$ \\
& $(1.76)$ & $(1.85)$ & $(-0.11)$ & $(1.21)$ & $(2.47)$ \\
Investors' sentiment & $28.92^{* * *}$ & $28.92^{* * *}$ & $7.553^{* * *}$ & $15.29^{* * *}$ & $27.62^{* * *}$ \\
& $(6.41)$ & $(5.71)$ & $(4.82)$ & $(4.12)$ & $(4.23)$ \\
Private placement & $-17.80^{* * *}$ & $-17.80^{* * *}$ & -2.104 & $-10.27^{* *}$ & $-17.69^{* *}$ \\
& $(-3.59)$ & $(-3.33)$ & $(-1.22)$ & $(-2.52)$ & $(-2.47)$ \\
Offer price & $-16.69^{* * *}$ & $-16.69 * * *$ & $-1.320^{*}$ & -5.056 & $-16.72^{* * *}$ \\
& $(-4.55)$ & $(-4.95)$ & $(-1.03)$ & $(-1.67)$ & $(-3.15)$ \\
\hline
\end{tabular}




\begin{tabular}{lccccc}
\hline \hline Variable & OLS & Robust OLS & & QR & \\
Reputable underwriters & $-8.518^{*}$ & $-8.518^{* *}$ & -1.740 & -3.961 & -8.494 \\
& $(-1.91)$ & $(-2.05)$ & $(-1.12)$ & $(-1.08)$ & $(-1.32)$ \\
Constant & $51.60^{* * *}$ & $51.60^{* * *}$ & $8.775^{* * *}$ & $25.80^{* * *}$ & $57.84 * * *$ \\
& $(6.89)$ & $(6.74)$ & $(3.37)$ & $(4.18)$ & $(5.34)$ \\
Number of obs. & 420 & 420 & 420 & 420 & 420 \\
R-squared & 0.180 & & & & \\
\hline \hline
\end{tabular}

Note: $* * *, * *, *$ denote significance at the 1 percent, 5 percent, and 10 percent levels, respectively; and $\tau$-statistic in parentheses.

The OLS results in Table 4 show that the lock-up period has a significant positive relationship with OSR at the 10 percent level. Moreover, the QR results show that the lock-up period has a significant positive relationship with OSR at the 5 percent level in the upper quantile ( 75 th). This means that in the case of IPOs with high subscription demand, investors start to rely on information regarding the period of the lock-up in identifying IPOs with higher initial return. According to Courteau (1995) longer lock-up periods are associated with higher cost on insiders, which means longer periods are associated with higher initial return. Furthermore, Mohd Rashid et al. (2014) documented that longer lock-up periods in Malaysia is associated with higher initial return. This also means that like reputable auditors, investors use the information regarding the lock-up period to evaluate the initial return of the listing firm than using the information in assessing the issuing firm's quality.

The control variable investors' sentiment investigates if the subscription for the listing firm's issue will be higher for IPOs with high initial returns. Low and Yong (2011) reported that investors would become more interested to invest in IPOs with higher initial returns during the first-day of listing, which influence investors' subscription leading to an increase in oversubscription (Tajuddin et al., 2018). According to Lowry and Schwert (2002) information regarding IPO initial return can be categorised as specific information known prior to the offering as well as new information that is available in the secondary market when the IPO starts trading. Furthermore, Yong (2015) and Low and Yong (2013) reported that investors' heterogeneous of opinion is higher for IPOs with high initial return than for IPOs with lower initial return due to higher demand for the issues with higher initial returns. The OLS and QR results in Table 4 show that investors' sentiment has a positive significant relationship with OSR al the 1 percent level. This means that investors' demand in the Malaysian market is motivated by the first-day initial return.

The OLS result in Table 4 shows that private placement has a significant negative effect on OSR at the 1 percent level. Moreover, the results of the QR shows that private placement has a negative significant result at the 5 percent level in both the medium and higher quantiles (50th, 75th, respectively). This means that IPOs with high institutional involvement have lower OSR. Yong (2011) found that the initial return for IPOs with institutional involvement is lower than IPOs without institutional involvement. This means that investors in the Malaysian market also evaluate the private placement information from the perspective of initial return, which is in alignment with the previous findings of the study.

We have established that the offer price in the fixed-price method is set between the issuing firm and the lead investment banker, where prospective investors' evaluations and expectations are not taken into consideration in the settled offer price. Furthermore, according to Moshirian et al. (2010) 
investors are driven by first-day capital gain. This means that if the offer price is high the possibility of first-day capital gain is lower for prospective investors. The OLS results in Table 4 shows that the offer price has a significant negative influence on OSR at the 1 percent level. Furthermore, the QR results show that the offer price has a significant negative effect on OSR at the 10 and 1 percent levels in the lower and higher quantiles (25th, 75th, respectively). This shows that the higher the offer price of the issues of the listing firm the lower the OSR.

Finally, the OLS results in Table 4 show that reputable underwriters have significant negative effect on OSR. This is in alignment with the literature that showed that reputable underwriter is able to signal the quality of the listing firm by lowering the under-pricing cost that the listing frim has to endure during the listing process. According to Sundarasen et al. (2017) IPOs with reputable underwriters in the Malaysian market are associated with lower initial return because of the ability of the reputable underwriter to set the offer price of IPOs as close as possible to the market/fair value of the shares.

\section{CONCLUSION}

In this study, we examined the signalling effect of auditor reputation and lock-up period on the subscription demand for the listing firm's issues in the Malaysian IPO market, where OSR is used as the proxy for subscription demand. The final study sample consisted of 420 IPOs listed on Bursa Malaysia from January 2000 until December 2015. Specifically, the present study investigated if investors' demand for IPOs is driven by capital gain or the quality of the issuing frim. The results indicate that reputable auditors have a significant negative effect on OSR, and the lock-up period has a positive significant effect on OSR. These results confirm the signalling effect of auditor reputation and lock-up period on OSR. However, investors in the Malaysian market have different interpretations for those signals, where prospective investors use the signalling effect in evaluating the first-day initial return and not the quality of the listing firm. This means that investors in the Malaysian market are more driven by the initial gain that they can achieve during the first-day of listing by demanding issues with less reputable auditors and have longer lock-up periods. These results suggest that we should revaluate how we interpret signalling in markets with high initial return because it is clearly that prospective investors in such markets are driven by capital gain. The control variables of the current study help us in confirming such trend in the Malaysian market. Looking at investors' sentiment, the results suggest that investors' demand is higher for IPOs with higher initial returns. Moreover, IPOs with high offer price face lower demand because higher offer price leads to lower initial return. Furthermore, IPOs with higher institutional involvement have lower investors' demand because such IPOs have lower initial returns. Finally, the control variable reputable underwriters help us in reaching the same conclusion that investors are more interested in capital gain than in the quality signalling effect. The results of the current study reflect the uniqueness of the Malaysian IPO market due to its reliance on the fixed-priced method in pricing IPOs.

Malaysia is one of the leading countries when it comes to Islamic finance. However, only a few studies, such as that of Abdul-Rahim and Yong (2008), Abdul-Rahim and Yong (2010), and AbdulRahim and Che-Embi (2013), attempted to examine the influence of Sharia-compliant status on the IPO under-pricing. Future research should identify more predictive variables that may explain the initial returns (or under-pricing) in the Malaysian IPO market with a focus on the implications 
of Sharia-compliant status. Finally, this study only considered the signalling effect of lock-up period and auditor reputation, future studies can take into considerations the effect of other signalling variables, such as underwriter reputation, board size, board education, independent board members, retention ratio.

\section{REFERENCES}

Abdul-Rahim, R., \& Che-Embi N. C. E., (2013). Initial returns of Shariah versus non-Shariah IPOs: Are there any differences? Jurnal Pengurusan, 39(1), 1-14.

Abdul-Rahim, R., \& Yong, O. (2010). Initial returns of Malaysian IPOs and Shari'a compliant status. Journal of Islamic Accounting and Business Research, 1(1), 60-74.

Abdul-Rahim, R., \& Yong, O., (2008). Initial returns of Shariah-compliant IPOs in Malaysia. Capital Market Review, 16(2), 270-279.

Alanazi, A. S., Liu, B., \& Al-Zoubi, H. A. (2016). IPO under-pricing in supply and demand framework: Evidence from a market of retailers. Applied Economics, 48(60), 5835-5849.

Albada, A., Low, S., \& Yong, O. (2019a). Prestige signals and heterogeneity of opinion regarding IPO values: Malaysian evidence. International Journal of Emerging Markets. Vol. ahead-of-print No. ahead-of-print. doi: 10.1108/IJOEM-04-2018-0170

Albada, A., Low, S. W., Yong, O., Nassir, A. M., Kamarudin, F., \& Anwar, N. A. M. A. (2019b). Heterogeneity of opinion, shareholder retention ratio and lockup period: Malaysian evidence. International Journal of Economics and Management, 13(1), 231-248.

Albada, A., Yong, O., \& Low, S. (2019c). Relationship between prestige signals and oversubscription ratio. International Journal of Managerial Finance, 15(4), 564-579.

Albada, A., Yong, O., Hassan, M. E. M, \& Abdul-Rahim, R. (2018). Retention ratio, lock-up period and prestige signals and their relationship with initial public offering (IPO) initial return: Malaysian evidence. Asian Academy of Management Journal of Accounting and Finance, 14(2), 1-23.

Allen, F., \& Faulhaber, G. R. (1989). Signalling by under-pricing in the IPO market. Journal of Financial Economics, 23(2), 303-323.

Badru, B. O., \& Ahmad-Zaluki, N. A. (2018). Explaining IPO initial returns in Malaysia: Ex ante uncertainty vs signalling. Asian Review of Accounting, 26(1), 84-106.

Beatty, R. P., \& Ritter, J. R. (1986). Investment banking, reputation, and the under-pricingof initial public offerings. Journal of Financial Economics, 15(1-2), 213-232.

Benveniste, L. M., \& Busaba, W. Y. (1997). Bookbuilding vs. fixed price: An analysis of competing strategies for marketing IPOs. Journal of Financial and Quantitative Analysis, 32(4), 383-403.

Bhabra, H. S., \& Pettway, R. H. (2003). IPO prospectus information and subsequent performance. Financial Review, 38(3), 369-397.

Boonchuaymetta, E., \& Chuanrommanee, W. (2013). Management of the IPO performance in Thailand. Journal of Multinational Financial Management, 23(4), 272-284.

Brav, A., \& Gompers, P. A. (2003). The role of lock-ups in initial public offerings. Review of Financial Studies, 16(1), 1-29.

Chowdhry, B., \& Sherman, A. (1996). International differences in over-subscription and underpricing of IPOs. Journal of Corporate Finance, 2(4), 359-381.

Courteau, L. (1995). Under-diversification and retention commitments in IPOs. Journal of Financial \& Quantitative Analysis, 30(4), 487-517. 
Dawson, M. S. (1987). Secondary stock market performance of initial public offers, Hong Kong, Singapore and Malaysia: 1978-1984. Journal of Business Finance and Accounting, 14(1), 65-76.

Dimovski, W., Philavanh, S., \& Brooks, R. (2011). Underwriter reputation and under-pricing: Evidence from the Australian IPO market. Review of Quantitative Finance and Accounting, 37(4), 409-426.

Grinblatt, M., \& Hwang, C. Y. (1989). Signalling and the pricing of new issues. Journal of Finance, 44(2), 393-420.

Haman, J., Chalmers, K., \& Fang, V. (2017). IPO lock-ups, long-run returns, and growth opportunities. Journal of International Financial Markets, Institutions and Money, 49, 184-199.

Huang, H., Chiang, M., Lin, J., \& Lin, Y. (2017). Fixed-price, auction, and book-building IPOs: Empirical evidence in Taiwan. Finance Research Letters, 22, 11-19.

Jelic, R., Saadouni, B., \& Briston, R. (2001). Performance of Malaysian IPOs: Underwriters reputation and management earnings forecasts. Pacific-Basin Finance Journal, 9(5), 457486.

Khurana, I., Ni, C., \& Shi, C. (2017). The role of big 4 auditors in the global primary market: Does audit quality matter most when investors are protected least? Paper presented at Asian bureau of finance and economic research annual conference, Gardenia, Azalea. Retrieved from http://abfer.org/media/abfer-events-2017/annual-conference/accounting/ac2017 p5008_the_role_of_big_4_auditors_in_the_global_primary_market.pdf

Ljungqvist, A. (2008). IPO under-pricing. In: Eckbo, B.E. (Ed.), Handbook of Empirical Corporate Finance ( $\left(1^{\text {st }}\right.$ Ed., pp. 375-422). North Holland: Elsevier Science.

Loughran, T. \& Ritter, J. R. (1995). The new issues puzzle. Journal of Finance, 50(1), 23-51.

Loughran, T., Ritter, J. R., \& Rydqvist, K. (1994). Initial public offerings: International insights. Pacific-Basin Finance Journal, 2(2\&3), 165-199.

Low, S. W., \& Yong, O. (2011). Explaining over-subscription in fixed-price IPOs: Evidence from the Malaysian stock market. Emerging Markets Review, 12(1), 205-216.

Low, S. W., \& Yong, O. (2013). Initial public offerings and investor heterogeneity: Evidence from Malaysia. American Journal of Finance and Accounting, 3(1), 41-56.

Lowry, M., Schwert, W.G. (2002). IPO market cycles: Bubbles or sequential learning? Journal of Finance, 57, 1171-1200.

Megginson, L., \& Weiss, A. (1991). Venture capitalist certification in initial public offerings. Journal of Finance, 46(3), 879-903.

Michaely, R., \& Shaw, W. H. (1994). The pricing of initial public offerings: Tests of adverseselection and signalling theories. Review of Financial Studies, 7(2), 279-319.

Michaely, R., \& Shaw, W. H. (1995). Does the choice of auditor convey quality in an initial public offering? Journal of the Financial Management Association, 24(4), 15-30.

Mohan, N., \& Chen, C. (2002). Information content of lock-up provisions in initial public offerings. International Review of Economics and Finance, 10(1), 41-59.

Mohd Rashid, R., Abdul-Rahim, R., \& Yong, O. (2014). The influence of lock-up provisions on IPO initial returns: Evidence from an emerging market. Economic Systems, 38(4), 487501.

Moshirian, F., Ng, D., \& Wu, E. (2010). Model specification and IPO performance: New insights from Asia. Research in International Business and Finance, 24(1), 62-74.

Ritter, J. R. (1998). Initial public offerings. Contemporary Finance Digest, 2(1), 5-30. 
Ritter, J. R., \& Welch, I. (2002). A review of IPO activity, pricing, and allocations. Journal of Finance, 57(4), 1795-1828.

Rock, K. (1986). Why new issues are under-priced. Journal of Financial Economics, 15(1-2), $187-212$.

Rumokoy, L. J., Neupane, S., Chung, R. Y., \& Vithanage, K. (2017). Underwriter network structure and political connections in the Chinese IPO market. Pacific-Basin Finance Journal, 54, 199-214.

Spence, M. (1973). Job market signalling. Quarterly Journal of Economics, 87(3), 355-374.

Spence, M. (2002). Signalling in retrospect and the informational structure of markets. American Economic Review, 92, 434-459.

Sundarasen, S. D., Khan, A., \& Rajangam, N. (2017). Signalling roles of prestigious auditors and underwriters in an emerging IPO market. Global Business Review, 19(1), 69-84.

Tajuddin, A. H, Abdullah, N. A. H., \& Taufil-Mohd, K. N. (2018). Shariah-compliant status and IPO oversubscriptions. Journal of Islamic Accounting and Business Research, 3(4), 531548.

Tajuddin, A. H., Mohd Rashid, R., Abdullah, N. A. H., \& Abdul-Rahim R. (2015). An empirical examination of over-subscription in the Malaysian IPO market. International Journal of Economics and Management, 9(S), 81-102.

Taufil-Mohd, K. N. (2007). Regulations and under-pricing of IPOs. Capital Markets Review, 15(1), 1-27.

Vong, A. P. (2006). Rate of subscription and after-market volatility in Hong Kong IPOs. Applied Financial Economics, 16(1), 1217-1224.

Welch, I. (1989). Seasoned offerings, imitation costs, and the under-pricing of initial public offerings. Journal of Finance, 44(2), 421-449.

Yong, O. (2007). A review of IPO research in Asia: What's next? Pacific-Basin Finance Journal, 15(3), 253-275.

Yong, O. (2015). What is the "true" value of an initial public offering? Journal of Scientific Research and Development, 2(10), 78-85.

Yong, O., \& Albada, A. (2018). Under-pricing and listing board in explaining heterogeneity of opinion regarding values of malaysian IPOs. Jurnal Pengurusan, 51, 63-72.

Yong, O., \& Isa, Z. (2003). Initial performance of new issues of shares in Malaysia. Applied Economics, 35(8), 919-930. 